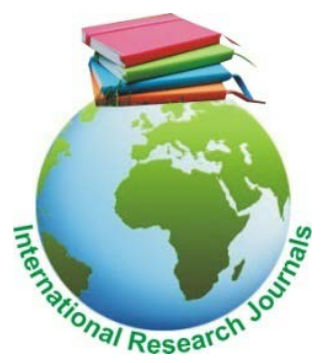

Full Length Research Paper

\title{
Production and evaluation of breakfast cereals from blends of acha, mung bean and orange fleshed sweet potato
}

\author{
Mbaeyi-Nwaoha IE*, Odo JE \\ ${ }^{1}$ FDepartment of Food Science and Technology, Faculty of Agriculture, University of Nigeria, Nsukka, Enugu \\ State, Nigeria, West Africa. \\ *Corresponding Author Email: ifeoma.mbaeyi-nwaoha@unn.edu.ng
}

\begin{abstract}
The study investigated the production of ready-to-eat breakfast cereals from acha, mung bean and orange fleshed sweet potato flours (from $0 \%$ to $100 \%$ ). The objectives of the study were to produce and evaluate the chemical, microbial and sensory profile ready-to-eat breakfast cereal from blends of acha, fermented mung bean and orange fleshed sweet potato flours. Acha, mung bean and orange fleshed sweet potato were processed into flour. Bulk density and water absorption capacity of acha, mung bean and orange fleshed sweet potato flour were determined. Preliminary studies were carried out to determine the best blend from acha:mung bean flour blends. On inclusion of orange flesh sweet potato, the flour blend for the formulated breakfast cereals, all the samples were subjected to functional, proximate, $\beta$-carotene, microbial and sensory analyses using standard procedures. The results showed that the best blend was from $90 \%$ acha and $10 \%$ mung bean flours for the breakfast cereals. There was an increase in the moisture, ash, fibre and $\beta$-carotene content of the breakfast cereals with a corresponding decrease in the protein and fat content as the graded levels of the orange fleshed sweet potato flour added to the blend increased. The addition of the orange flesh improved the 1.24 to $3.04 \mathrm{mg} / 100 \mathrm{~g}$. There was no mould growth in the formulated ready-to-eat breakfast cereals
\end{abstract}

Keywords: Acha, Flaked breakfast cereals, Mung bean, Orange fleshed sweet potato

\section{INTRODUCTION}

The burden of micronutrient malnutrition among the population of Africa especially children under five are high in sub-Saharan Africa compared with other regions (Caulfied et al., 2006). Zinc, iron, and vitamin A is identified by the World Health Organization as the most limiting in the diets of the poor (Dewey, 2001). Consumers are today demanding for an ever broadening selection of more convenient light meal, low calorie, and high nutritional food products. Therefore of great importance, is the possibility of developing low cost breakfast cereal that provides necessary nutrients required by the body. Breakfast meals vary widely in different cultures around the world. It often includes a carbohydrate source such as cereals, fruit and or vegetable, protein, sometimes dairy, and beverage (Rampersaud et al., 2005). Eating breakfast made mostly from cereals provides energy and enhances productivity and mental performance; they are not usually consumed alone but supplemented with other food in order to make up for the deficiencies found in cereals (Enwere and Ntuen, 2005).

Breakfast cereals are legally defined as foods obtained by swelling, grinding, rolling or flaking of any cereal (Sharma and Caralli, 2004). Ready-to-eat (RTE) cereals ranks as one of the best choices available as part of a nutritious breakfast. Ready-to-eat cereals facilitate independence because of their ease of preparation which means that children and adolescents can be responsible for their own breakfast or snacks (Jones, 2003). Such foods may need to be reconstituted, pre-heated in a vessel or allowed to thaw if frozen before consumption, or they may be eaten directly without further treatment (Okaka, 2005). Almost all over the world, breakfast cereals have become firmly 
established on breakfast tables. In addition to a wide variety of forms, taste and colours, they are expected today to also meet a stringent nutritional requirement. Eating breakfast has been shown to be beneficial for both body and mind in several ways. Those who eat cereal-based breakfast cereals have a lower Body Mass Index (BMI) than those who skip breakfast or choose an alternative breakfast options (Hunty and Ashwell, 2006).

The amount of cereal grown in Nigeria is high compared to its utilization. This is due to post harvest losses incurred from cereals, thus there is need to diversify the use of cereals into producing some products which can be made available all year. Acha one of the oldest cereal grain of Digitaria spp is one of the most nutritious of all grains but it is regarded as food for the poor (Omeire, 2013). Adapted to poor soils and limited water supply, acha is an excellent dry area crops which grows and produces where other crops fail (Vodouhe et al., 2012). Like other millets, acha is widely reported to be rich in amino acids but particularly in the amino acid methionine and cysteine which supply sulphur and other compounds required by the body for normal metabolism and growth (Belton and Nuttall, 2002). Some acha varieties are world's fastest maturing cereals and can produce grains in just $6-8$ weeks. Acha is still underutilized because of difficulty resulting from its very tiny seeds. It is rich in methionine, an essential amino acid vital in human health that is deficient in most cereals. Acha helps in lowering the blood glucose level thereby reducing diabetes. Despite the benefits associated with this cereal, it is still among the cereals which are underutilized.

Mung bean (Vigna radiata) is still underutilized as food due to its tough texture, long cooking time and lack of education on its nutritional composition. Its consumption is occasional. Mung bean can provide significant amounts of protein $(240 \mathrm{~g} / \mathrm{kg})$, carbohydrate $(630 \mathrm{~g} / \mathrm{kg})$ and a range of micronutrients in diets (Anwar et al., 2007). Mung bean protein and carbohydrates are easily digested and create less flatulence than those derived from other legumes. The mung bean lysine content of $504 \mathrm{mg} / \mathrm{g}$ makes it a good supplement for most cereal based diets which lack this essential amino acid (Baskaran et al., 2009). The high lysine content of mung bean makes them an excellent enhancer of protein quality when combined with cereal grain proteins (Ashraf, 2006). Mung beans are a good source of energy, proteins, vitamins (thiamin, and a good source of folate), minerals (iron, magnesium) and dietary fibre.

Orange fleshed sweet potato is a breed of sweet potato that is bio fortified with vitamin A. Sweet potato is generally recognized as being an underutilized nutritious food (Bovell-Benjamin, 2007). Beyond 'boil' and 'eat', orange fleshed sweet potato can be processed into various commercial products and can be used to enrich indigenous foods.
The study is useful in the improvement of the nutritional quality of cereals by complementing their limiting amino acid with legumes. This study would also provide avenue for the utilization of acha, mung bean and orange fleshed sweet potato, which are presently underutilized as raw materials for industrial production of breakfast cereals. The product from the study would go a long way in addressing macro and micro-nutrient deficiencies among consumers especially children. The data obtained from this study could play an important role as reference material or baseline for researchers, health and nutrition policy makers, dietary counsellors as well as households (Usman, 2009).

The main thrust of the study was to produce and evaluate ready-to-eat breakfast cereal from blends of acha, fermented mung bean and orange fleshed sweet potato.

\section{MATERIALS AND METHODS}

\section{Procurement of Raw Materials}

Mung bean seeds, salt and sugar were purchased from Ogige market, Nsukka in Enugu state, Nigeria. Acha grains were purchased from Babangida market, Suleja in Niger state, Nigeria while orange fleshed sweet potato (UMUS ${ }^{013}$ ) was purchased from National Root Crop Research Institute (NRCRI), Umudike in Abia state, Nigeria.

\section{Processing of Raw Materials}

Acha, mung bean and orange fleshed sweet potato were processed into flour using different methods.

\section{Processing of acha grains to flour}

Acha was processed into flour using the method described by Olapade et al. (2010) with slight modification in drying time from 4-6 h. Two kilograms (2 kg) of the grains were cleaned by sorting and winnowing, then washed in several changes of excess water to separate stone and sand. The cleaned acha was then dried in an oven (Fulton, model NYC-101) at $50^{\circ} \mathrm{C}$ for 6 hours. The dried acha was milled into flour using hammer mill (Thomas Wiley mill Model ED-5), packaged in an air tight container and stored for further use. The flow diagram for the processing of acha into flour is shown in Figure 1.

\section{Processing of mung bean to flour}

Mung bean was processed into flour using the method described by Onwurafor et al. (2014) with slight modification by soaking for $24 \mathrm{~h}$ instead of $12 \mathrm{~h}$ by these authors. Two kilogram (2 kg) of the mung bean seeds were cleaned by winnowing and hand-sorting.

The seeds were washed and fermented by soaking in distilled water for $24 \mathrm{~h}$. During the soaking, the water was changed after $12 \mathrm{~h}$. The fermented mung bean was then dried in an oven (Fulton, model NYC-101) at $65^{\circ} \mathrm{C}$ for 


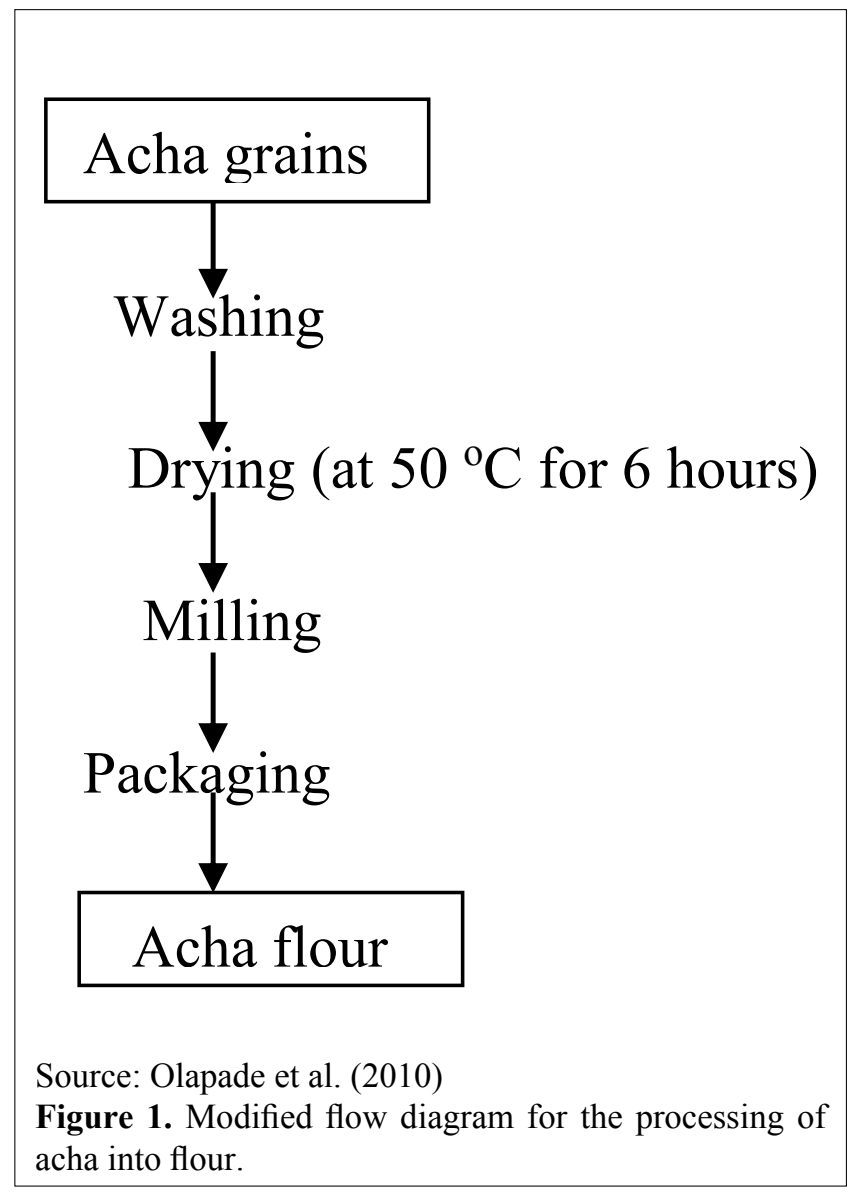

$12 \mathrm{~h}$ and milled into flour using a hammer mill (Thomas Wiley mill Model ED-5) and sieved through $4.25 \mu \mathrm{m}$ pore size sieve. The resultant flour was then packaged in an airtight container for further use. The flow diagram for the processing of mung bean into flour is shown in Figure 2.

\section{Processing of orange fleshed sweet potato into flour}

Orange fleshed sweet potato was processed in to flour using the procedure described by Laryea (2016). Orange fleshed sweet potatoes were sorted, peeled, chipped and dried. The dried sweet potato chips were then milled in a hammer mill (Thomas Wiley mill Model ED-5) into flour and packaged in an air tight container for further use. The flow diagram for the processing of orange fleshed sweet potato to flour is shown in Figure 3.

\section{Preparation of Flour Blends}

Acha flour (AC) and Mung Bean flour (MB) were blended in the ratio $100: 0,90: 10,80: 20,70: 30,60: 40,50: 50$ and breakfast cereals produced from the blend. The resultant breakfast cereals were subjected to sensory evaluation in order to obtain the best blend (90:10). Composite flour was formulated by mixing Acha flour (AC) and Mung bean flour (MB) in the ratio 90:10. Samples of breakfast cereals were generated by mixing composite flour (acha and mung bean flour) with graded levels of Orange fleshed

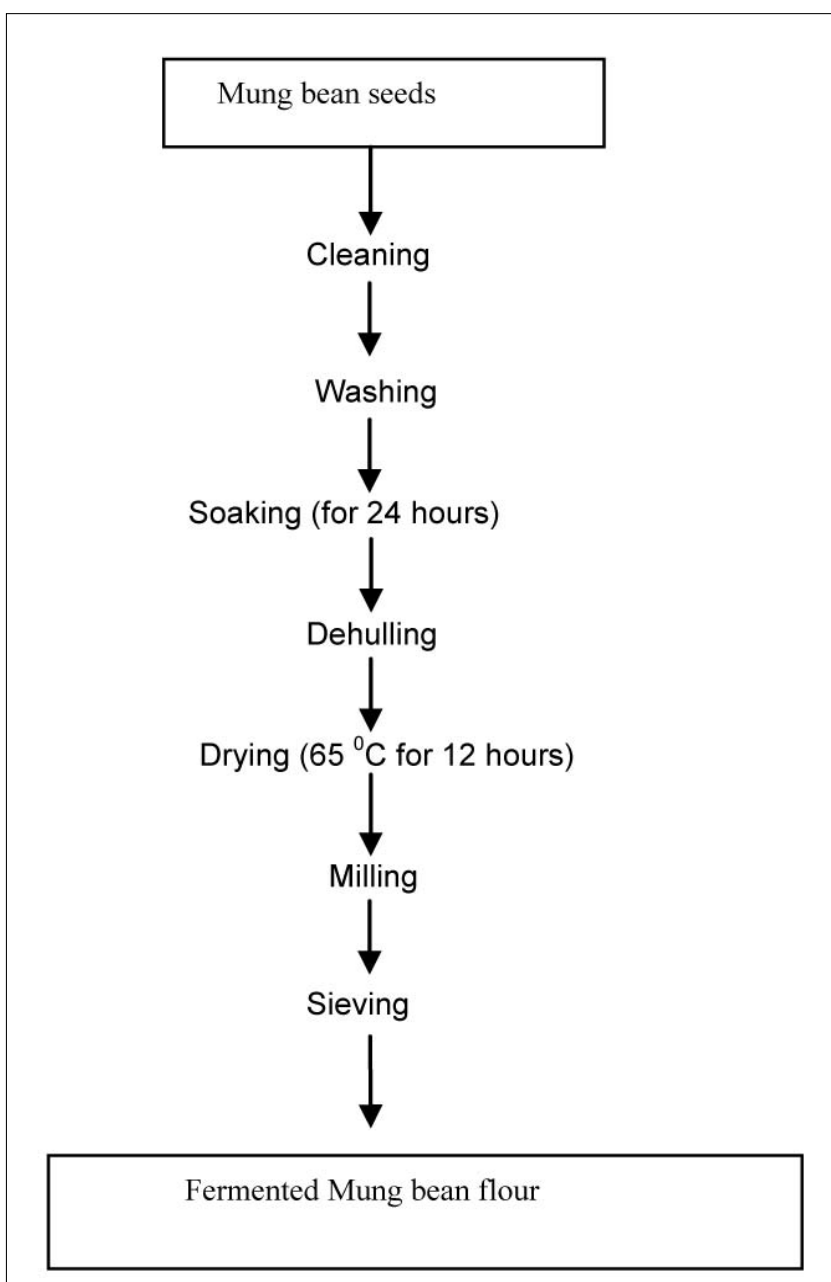

Source: Onwurafor et al. (2014)

Figure 2. Modified flow diagram for the Processing of mung bean into flour

sweet potato flour (OP) with 100\% acha and 100\% mung bean as the control.

\section{Production of Breakfast Cereals}

Determination of bulk density and water absorption capacity of flour samples

Bulk density and water absorption capacity of the flour samples were determined using the method described by Onwuka (2005) Figure 4.

Determination of Moisture, Fat, Ash, Protein and Crude Fibre Contents of the Flour Samples and Formulated Breakfast Cereals

The moisture, fat, ash, protein and crude fibre contents of the flour samples and formulated breakfast cereals were determined by the method of AOAC (2010).

\section{Determination of Carbohydrate Content}

The Carbohydrate was determined by difference as follows: 


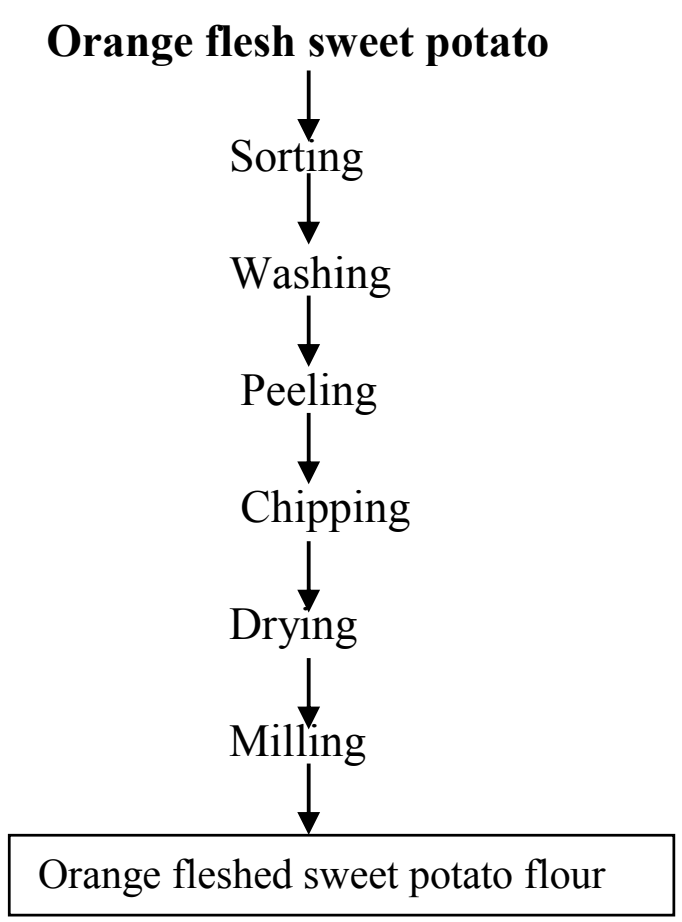

Source: Laryea (2016)

Figure 3. Processing of orange fleshed sweet potato into flour.
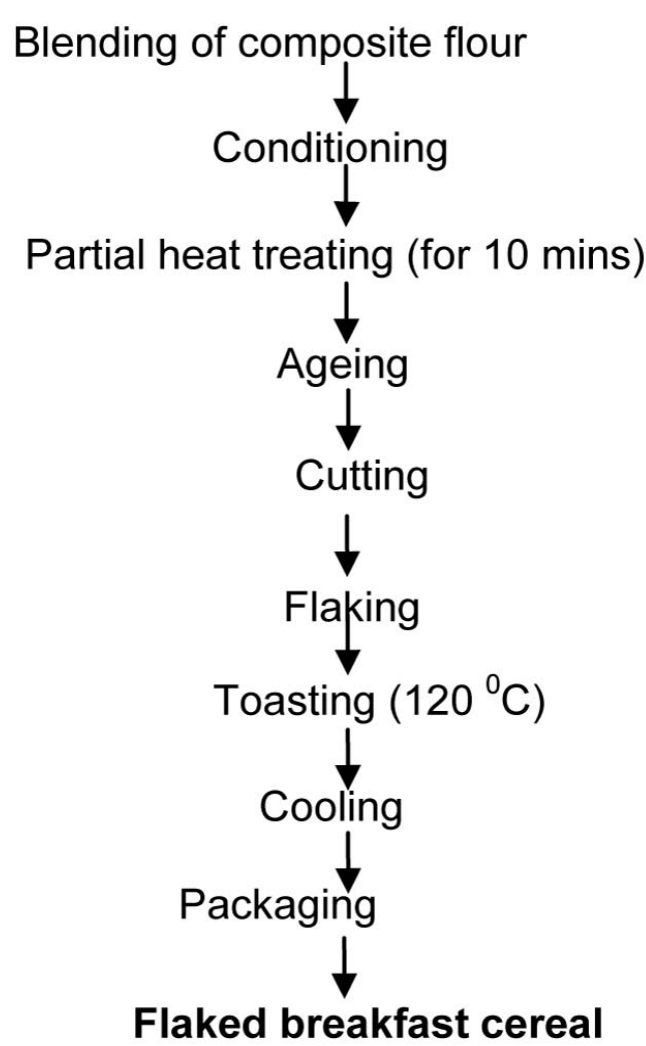

Source: Mbaeyi-Nwaoha and Uchendu (2016)

Figure 4. Flow diagram for the production of ready- toeat breakfast cereal
\%Carbohydrates=100- $(\%$ moisture+\%fat+\%ash+\%protei $n+\%$ crude fibre).

\section{Determination $\beta$-carotene}

The $\beta$-carotene content was determined using Kirk and Sawyer (1998) method.

\section{Microbial Count Determination}

The total viable count was determined by the pour plate count method as described by Prescott et al. (2005) while the pour plate method for the mould count was as described by Harrigan and McCance (1976).

\section{Sensory Evaluation}

Sensory evaluation of the samples was evaluated by 20 semi-trained panelists from the Department of Food Science and Technology for various sensory attributes (appearance, taste, colour, texture, after taste and overall acceptability). A 9-point Hedonic scale was used where " 9 " represents extremely like and " 1 " represents extremely dislike (Ihekoronye and Ngoddy, 1985).

\section{Experimental Design and Data Analysis}

The experiment was conducted in a Completely Randomized Design (CRD). Data obtained were subjected to one-way Analysis of Variance (ANOVA) and mean separation was done by Duncan multiple range test, using Statistical Product for Service Solution (SPSS) version 20 and significance difference was accepted at $\mathrm{p}<0.05$ (Steel and Torre, 1980).

\section{RESULTS AND DISCUSSION}

Proximate Composition, $\beta$-carotene, Water Absorption Capacity and Bulk Density Content of Acha, Mung Bean and Orange Fleshed Sweet Potato Flour

The proximate composition (\%), $\beta$-carotene (mg/100 g), water absorption capacity (\%) and bulk density $\left(\mathrm{g} / \mathrm{cm}^{3}\right)$ contents of acha, mung bean and orange fleshed sweet potato flour are presented in the Table 1.

\section{Sensory Scores of Breakfast Cereal Produced from Acha and Mung Bean Flour.}

The sensory scores of breakfast cereal formulated from acha and mung bean flour is shown in Table 2 .

The scores for colour of the breakfast cereal ranged from $5.15\left(\mathrm{AC}+\mathrm{MB}_{5}\right)$ to $7.15\left(\mathrm{AC}+\mathrm{MB}_{1}\right)$. There was no significant $(p<0.05)$ difference between the samples and control $\left(A C+M B_{0}\right)$ except for sample $A C+M B_{5}$. Sample $\mathrm{AC}+\mathrm{MB}_{1}$ ranked highest followed by sample $\mathrm{AC}+\mathrm{MB}_{0}$ (control). From Table 2, it was observed that the judges preferred the colour of sample $\mathrm{AC}+\mathrm{MB}_{1}$ although it was not significantly $(p<0.05)$ different from sample $A C+M B_{0}$ (control). The scores for colour decreased with increased 
Table 1. Proximate composition (\%) and $\beta$-carotene ( $\mathrm{mg} / 100 \mathrm{~g}$ ) content of acha, mung bean and orange fleshed sweet potato flour.

\begin{tabular}{|c|c|c|c|}
\hline \multirow{2}{*}{ Parameters } & \multicolumn{3}{|c|}{ Sample code } \\
\cline { 2 - 4 } & AC & MB & OP \\
\hline Moisture (\%) & $10.42^{\mathrm{c}} \pm 0.03$ & $12.33^{\mathrm{b}} \pm 0.03$ & $15.58^{\mathrm{a}} \pm 0.02$ \\
\hline Protein (\%) & $10.89^{\mathrm{b}} \pm 0.04$ & $21.94^{\mathrm{a}} \pm 0.06$ & $1.94^{\mathrm{c}} \pm 0.04$ \\
\hline Ash (\%) & $3.21^{\mathrm{b}} \pm 0.05$ & $2.83^{\mathrm{c}} \pm 0.04$ & $4.34^{\mathrm{a}} \pm 0.01$ \\
\hline Fat (\%) & $0.73 \pm 0.04$ & $3.99 \pm 2.16$ & $0.95 \pm 0.01$ \\
\hline Fibre (\%) & $3.12^{\mathrm{c}} \pm 0.05$ & $3.91^{\mathrm{b}} \pm 0.05$ & $4.54^{\mathrm{a}} \pm 0.06$ \\
\hline CHO (\%) & $71.63^{\mathrm{a}} \pm 0.13$ & $49.93^{\mathrm{b}} \pm 9.18$ & $72.35^{\mathrm{a}} \pm 0.05$ \\
\hline B-carotene (mg/100 g) & $0.75^{\mathrm{b}} \pm 0.06$ & $0.22^{\mathrm{c}} \pm 0.04$ & $7.86^{\mathrm{a}} \pm .05$ \\
\hline WAC (\%) & $119.70^{\mathrm{c}} \pm 4.24$ & $155.10^{\mathrm{b}} \pm 0.70$ & $264.90^{\mathrm{a}} \pm 5.65$ \\
\hline Bulk Density (g/cm $\mathbf{3})$ & $0.81^{\mathrm{a}} \pm 0.01$ & $0.70^{\mathrm{b}} \pm 0.01$ & $0.65^{\mathrm{c}} \pm 0.01$ \\
\hline
\end{tabular}

Values are means \pm Standard Deviation (SD) of duplicate determinations. Values having the same superscript $(a, b$ and $c)$ within the same column are not significantly $(p>0.05)$ different.

AC: Acha Flour; MB: Mung Bean flour; OP: Orange fleshed sweet potato flour;

CHO:Carbohydrate; WAC:Water Absorption Capacity

Table 2. Sensory scores of breakfast cereal formulated from acha and mung bean flour.

\begin{tabular}{|c|c|c|c|c|c|c|}
\hline Sample code & Colour & Taste & Texture & Aftertaste & Appearance & Overall acceptability \\
\hline $\mathrm{AC}+\mathrm{MB}_{0}$ & $6.70^{\mathrm{a}} \pm 0.40$ & $7.15^{\mathrm{ab}} \pm 0.22$ & $6.75^{\mathrm{ab}} \pm 0.32$ & $7.00^{a} \pm 0.32$ & $6.15^{\mathrm{ab}} \pm 0.43$ & $6.90^{\mathrm{ab}} \pm 0.32$ \\
\hline $\mathrm{AC}+\mathrm{MB}_{1}$ & $7.15^{a} \pm 0.31$ & $7.45^{a} \pm 0.31$ & $7.15^{a} \pm 0.25$ & $7.50^{a} \pm 0.29$ & $7.20^{\mathrm{a}} \pm 0.40$ & $7.65^{a} \pm 0.29$ \\
\hline $\mathrm{AC}+\mathrm{MB}_{2}$ & $6.60^{a} \pm 0.26$ & $6.15^{b c} \pm 0.30$ & $6.35^{\mathrm{abc}} \pm 0.35$ & $5.95^{b} \pm 0.33$ & $5.80^{b c} \pm 0.35$ & $6.35^{\mathrm{bc}} \pm 0.32$ \\
\hline $\mathrm{AC}+\mathrm{MB}_{3}$ & $6.40^{\mathrm{a}} \pm 0.37$ & $5.75^{\circ} \pm 0.43$ & $5.90^{\mathrm{bc}} \pm 0.45$ & $5.95^{b} \pm 0.33$ & $6.15^{\mathrm{ab}} \pm 0.37$ & $5.70^{\mathrm{cd}} \pm 0.38$ \\
\hline $\mathrm{AC}+\mathrm{MB}_{4}$ & $6.10^{\mathrm{ab}} \pm 0.42$ & $5.00^{\text {cd }} \pm 0.40$ & $5.40^{\mathrm{cd}} \pm 0.43$ & $4.80^{\circ} \pm 0.35$ & $5.30^{\mathrm{bc}} \pm 0.44$ & $5.05^{\mathrm{de}} \pm 0.41$ \\
\hline $\mathrm{AC}+\mathrm{MB}_{5}$ & $5.15^{b} \pm 0.46$ & $3.95^{\mathrm{d}} \pm 0.59$ & $4.60^{\mathrm{d}} \pm 0.51$ & $4.15^{\circ} \pm 0.48$ & $4.80^{\circ} \pm 0.47$ & $4.15^{e} \pm 0.53$ \\
\hline
\end{tabular}

Values are means \pm Standard Error of Means (SEM) of 20 panelists. Values having the same superscript within the same column are not significantly $(p<0.05)$ different $(a, b, c$ and $d)$

Key: $A C+M B_{0}=100 \%$ acha $+0 \%$ mung bean; $A C+M B_{1}=90 \%$ acha flour $+10 \%$ mung bean flour; $A C+M B_{2}=80 \%$ acha flour $+20 \%$ mung bean flour; $A C+M B_{3}=70 \%$ acha flour $+30 \%$ mung bean flour; $A C+M B_{4}=60 \%$ acha flour $+40 \%$ mung bean flour; $A C+M B_{5}=50 \%$ acha flour $+50 \%$ mung bean flour.

substitution with mung bean flour. It was also observed that the preference for the samples in terms of colour decreased with increased addition of mung bean flour.

Taste of the formulated breakfast cereal ranged from $3.95\left(\mathrm{AC}+\mathrm{MB}_{5}\right)$ to $7.45\left(\mathrm{AC}+\mathrm{MB}_{1}\right)$. Sample $\mathrm{AC}+\mathrm{MB}_{1}$ was highly rated compared to other formulated samples. This showed that it was preferred to other samples and could be attributed to improvement in the taste of the breakfast cereal by the fermented mung bean flour. There was no significant $(p<0.05)$ difference between the taste of sample $A C+M B_{1}$ and $A C+M B_{0}$ (control). This could imply that blending acha and mung bean in the ratio of $90: 10$ $\left(A C+M B_{1}\right)$ for breakfast cereal production would not affect its acceptability in terms of taste.

Table 2 shows that texture of the formulated breakfast cereal ranged from $4.60\left(A C+M B_{5}\right)$ to $7.15\left(A C+M B_{1}\right)$. There was no significant $(p<0.05)$ difference between the texture of sample $A C+M B_{1}$ and that of the control $\left(A C+M B_{0}\right)$. The scores for texture of sample $\left(A C+M B_{1}\right)$ was highest as shown in Table 2. This showed that it was highly preferred relative to other samples. Texture is the prevailing textural characteristics of the product at the point of consumption that usually determine whether a food product could be swallowed or chewed (Edet et al., 2017). From Table 2, it was observed that the mean values for the texture decreased as the addition of mung bean exceed $10 \%$ but its addition at this level improved the texture of the breakfast cereal. This is in agreement with the findings of Chukwu and Abdul-kadir (2008) as well as Mbaeyi-Nwaoha and Uchendu (2016).

The scores for the aftertaste of the breakfast cereals ranged from $4.15\left(A C+M B_{5}\right)$ to $7.50\left(A C+M B_{1}\right)$. Sample $A C+M B_{1}$ was mostly preferred by the panelists although no significant $(p>0.05)$ different exist between the aftertaste of the sample $\left(A C+M B_{1}\right)$ and sample $A C+M B_{0}$ (control). The preference for the breakfast cereal in terms of aftertaste decreased as the quantity of acha in the blend decreased.

The sensory scores for the appearance of the breakfast cereal ranged from $4.80\left(\mathrm{AC}+\mathrm{MB}_{5}\right)$ to $7.20\left(\mathrm{AC}+\mathrm{MB}_{1}\right)$. The appearance of sample $A C+M B_{1}$ was highly preferred by the judges relative to other samples although no significant $(p<0.05)$ difference exist between the sample $\left(\mathrm{AC}+\mathrm{MB}_{1}\right)$ and sample $\mathrm{AC}+\mathrm{MB}_{0}$ (control). The appearance of the all the breakfast cereal were generally acceptable by the panelists.

The mean score for the overall acceptability of the formulated breakfast cereals ranged from 4.15 (sample $A C+M B_{5}$ ) to $7.65\left(\right.$ sample $\left.A C+M B_{1}\right)$. There was a general decrease in the overall acceptability of the breakfast cereal with a decrease in acha flour and increase in mung bean flour. This is similar to the findings of Agu et al. (2014) who has it that the overall acceptability of biscuit produced from acha flour, bambara groundnut flour and unripe plantain flour decreased with increased 
Table 3. Proximate composition $(\%)$ and $\beta$-carotene $(\mathrm{mg} / 100 \mathrm{~g})$ content of breakfast cereal formulated from acha, mung bean and sweet potato blends.

\begin{tabular}{|c|c|c|c|c|c|c|c|}
\hline \multirow{2}{*}{ Sample code } & Moisture & Protein & Ash & Fat & \multirow{2}{*}{ Fibre (\%) } & $\mathrm{CHO}$ & $\beta$-carotene \\
\hline & (\%) & (\%) & (\%) & (\%) & & (\%) & $(\mathrm{mg} / 100 \mathrm{~g})$ \\
\hline UAC & $6.60^{9} \pm 0.14$ & $9.76^{d} \pm 0.20$ & $3.54^{d} \pm 0.42$ & $0.25^{\mathrm{d}} \pm 0.07$ & $2.89^{e} \pm 0.07$ & $76.96^{a} \pm 0.91$ & $0.53^{9} \pm 0.01$ \\
\hline UMB & $8.32^{\mathrm{e}} \pm 0.26$ & $18.92^{\mathrm{a}} \pm 0.11$ & $2.86^{e} \pm 0.08$ & $1.83^{c} \pm 0.05$ & $3.77^{\mathrm{d}} \pm 0.07$ & $64.31^{\circ} \pm 0.57$ & $0.11^{f} \pm 0.01$ \\
\hline $\mathrm{ACMB}_{1}+\mathrm{OP}_{1}$ & $7.28^{f} \pm 0.15$ & $12.07^{b} \pm 0.11$ & $4.41^{\mathrm{c}} \pm 0.06$ & $2.66^{a} \pm 0.06$ & $3.94^{c} \pm 0.06$ & $69.63^{b} \pm 0.44$ & $1.24^{e} \pm 0.00$ \\
\hline $\mathrm{ACMB}_{2}+\mathrm{OP}_{2}$ & $8.97^{d} \pm 0.21$ & $10.36^{c} \pm 0.16$ & $5.05^{\mathrm{b}} \pm 0.06$ & $2.54^{\mathrm{ab}} \pm 0.65$ & $4.24^{b} \pm 0.08$ & $68.85^{\mathrm{b}} \pm 1.17$ & $1.81^{d} \pm 0.01$ \\
\hline $\mathrm{ACMB}_{3}+\mathrm{OP}_{3}$ & $9.52^{\mathrm{c}} \pm 0.78$ & $9.65^{\mathrm{d}} \pm 0.06$ & $5.25^{\mathrm{b}} \pm 0.06$ & $2.03^{\mathrm{bc}} \pm 0.10$ & $4.34^{b} \pm 0.06$ & $69.21^{\mathrm{b}} \pm 0.37$ & $2.25^{\circ} \pm 0.01$ \\
\hline $\mathrm{ACMB}_{4}+\mathrm{OP}_{4}$ & $10.38^{b} \pm 0.06$ & $9.11^{e} \pm 0.05$ & $5.46^{\mathrm{b}} \pm 0.08$ & $1.67^{\circ} \pm 0.09$ & $4.60^{\mathrm{a}} \pm 0.02$ & $68.78^{b} \pm 0.31$ & $2.69^{b} \pm 0.21$ \\
\hline $\mathrm{ACMB}_{5}+\mathrm{OP}_{5}$ & $11.20^{\mathrm{a}} \pm 0.14$ & $8.56^{\ddagger} \pm 0.05$ & $5.98^{a} \pm 0.05$ & $1.43^{c} \pm 0.04$ & $4.71^{\mathrm{a}} \pm 0.02$ & $68.18^{b} \pm 0.03$ & $3.04^{a} \pm 0.28$ \\
\hline
\end{tabular}

Values are means \pm standard deviation of duplicate determinations. Values having different superscripts are significantly $(p<0.05)$ different. Key: AC: Acha flour; MB: Mung bean flour; OP: Orange fleshed sweet potato flour

UAC: 100\% Acha flour; UMB: 100\% Mung bean flour; ACMB1+OP1: 90\% best blend+10\% orange fleshed sweet potato; ACMB2+OP2: $80 \%$ best blend $+20 \%$ orange fleshed sweet potato; ACMB3+OP3: $70 \%$ best blend $+30 \%$ orange fleshed sweet potato; ACMB4+OP4: $60 \%$ best blend $+40 \%$ orange fleshed sweet potato; ACMB5+OP5: $50 \%$ best blend $+50 \%$ orange fleshed sweet potato flours

addition of bambara groundnut flour and unripe plantain flour. Sample AC+MB ${ }_{1}$ had the highest mean score (7.65) in overall acceptability which made the breakfast cereal most acceptable to the judges although it was not $\mathrm{s}$ ignificantly $(p<0.05)$ different from the control $\left(A C+M B_{0}\right)$.

Generally, sample $A C+M_{1}(90 \%$ acha $+10 \%$ mung bean $)$ had the highest mean score in all parameters assessed which indicates that the sample $\left(A C+M B_{1}\right)$ was most preferred by the judges and was selected as the best blend for further substitution with orange fleshed sweet potato.

\section{Proximate Composition and $\beta$-carotene Content of the Breakfast Cereal}

Table 3 shows the proximate composition (\%) and $\beta$-carotene $(\mathrm{mg} / 100 \mathrm{~g})$ content of breakfast cereals formulated from acha, mung bean and orange fleshed sweet potato flour blends.

The moisture content of the formulated breakfast cereal ranged from $6.60 \%$ (sample UAC) to $11.20 \%$ (sample $\left.\mathrm{ACMB}_{5}+\mathrm{OP}_{5}\right)$. There was a significant $(p<0.05)$ difference in the moisture content of the samples. The moisture content of the formulated breakfast cereal samples increased as blending level of sample OP increased. This is in agreement with Kidane et al. (2013) who stated that increased addition of orange fleshed sweet potato flour increased the moisture content of the bread produced from wheat and orange fleshed sweet potato flour. This could be attributed to the ability of the total high fibre in orange fleshed sweet potato to interact with large amount of water through the hydroxyl group existing in the fibre structure.

The protein content (\%) of the samples ranged from $18.92 \%$ (sample UMB) to $8.50 \%$ (sample $\mathrm{ACMB}_{1}+\mathrm{OP}_{1}$ ). There was a significant $(p<0.05)$ difference in the protein content of the samples. The protein content of the sample decreased with increasing blend of orange fleshed sweet potato flour. Among the blended samples, $\mathrm{ACMB}_{1}+\mathrm{OP}_{1}$ $(12.04 \%)$ had the highest protein content with a decrease through to sample $\mathrm{ACMB}_{5}+\mathrm{OP}_{5}(8.50 \%)$ which had the lowest. This was in agreement with the findings of Kidane et al. (2014) who produced bread from orange fleshed sweet potato and wheat and lgbabul et al. (2014) who also produced bread from wheat, maize and orange fleshed sweet potato. The decrease in protein content could be attributed to the low protein content of the orange fleshed sweet potato flour (Kidane et al., 2013; Bartova and Bárta, 2009).

The ash content (\%) of the formulated breakfast cereal showed significant $(p<0.05)$ differences with values ranging from $2.86 \%$ (sample UMB) to $5.98 \%$ (sample $\mathrm{ACMB}_{5}+\mathrm{OP}_{5}$ ). Lower value of 1.50 to $2.50 \%$ was recorded by Mbaeyi, (2005) who used sorghum and pigeon pea to formulate breakfast cereal and higher value $5.29 \%$ to 7.36\% (Usman, 2009) who formulated breakfast cereal from African yam bean, maize and defatted coconut. This variation could be attributed to the use of different raw materials in formulation of the product. As the graded levels of orange fleshed sweet potato increased in the composite flour, the ash content of the blend increased. This was in agreement with the findings of Temesgen et al. (2015) who blended orange fleshed sweet potato and wheat flours for cookies production.

Table 3 shows that the fat content (\%) of the breakfast cereal ranged from $0.25 \%$ (sample UAC) to $2.66 \%$ $\left(\right.$ sample $\left.A C M B_{1}+O P_{1}\right)$. There were significant $(p<0.05)$ differences among the samples. The presence of graded levels of orange fleshed sweet potato in the formulation could be responsible for the generally low fat content of the resulting products. Higher values $(8.70 \%-14.2 \%)$ were recorded for breakfast cereals made from sorghum and pigeon pea blends (Mbaeyi, 2005).

Table 3 shows that the fibre content (\%) of the breakfast cereal ranged from $2.89 \%$ (sample UAC) to $4.71 \%$ (sample $\left.\mathrm{ACMB}_{5}+\mathrm{OP}_{5}\right)$. There were significant $(\mathrm{p}<0.05)$ differences among the samples and the crude fibre content increased with increase addition of orange fleshed sweet potato in the blend. This was similar to the findings of Singh et al. (2008) and Temesgen et al. (2015) who incorporated orange fleshed sweet potato in their blends. This could be attributed to the increased fibre content of orange fleshed 
sweet potato in the blend.

The carbohydrate content ranged from $76.96 \%$ (UAC) to 64.31\% (UMB) where sample UAC (76.96\%) being the control had highest value and the least UMB (64.31\%). The samples had higher values of carbohydrate due to the presence of acha (cereal) and orange fleshed sweet potato.

Table 3 shows the $\beta$-carotene content of the formulated breakfast cereal. The $\beta$-carotene content of the breakfast cereals formulated with orange fleshed sweet potato ranged from $1.24 \mathrm{mg} / 100 \mathrm{~g}$ (sample $\mathrm{ACMB}_{1}+\mathrm{OP}_{1}$ ) to $3.04 \mathrm{mg} / 100 \mathrm{~g}$ (sample $\mathrm{ACMB}_{5}+\mathrm{OP}_{5}$ ) and in control samples it was relatively low $(0.11 \mathrm{mg} / 100 \mathrm{~g}$ for UMB and $0.53 \mathrm{mg} / 100 \mathrm{~g}$ for UAC). The $\beta$-carotene increased with increased addition of orange fleshed sweet potato flour to the blend. This could be attributed to the high $\beta$-carotene content of orange fleshed sweet potato (Temesgen et al., 2015).

\section{Microbial Count (cfu/g) and Sensory Scores of the Breakfast Cereals Formulated from Acha, Mung Bean and Orange Fleshed Sweet Potato Flour}

Table 4 shows the total viable and mould count of the formulated breakfast cereal from acha, mung bean and orange fleshed potato flour. The total viable count of the formulated samples ranged from $3.1 \times 10^{3}$ (sample UAC) to $8.3 \times 10^{3}$ (sample $\mathrm{ACMB}_{3}+\mathrm{OP}_{3}$ ) cfu/g. The variation in the microbial load might be attributed to handling of the product after processing. However, the microbial loads of the sample were generally low. There was no mould growth in all the formulated breakfast cereals which could be attributed to the low moisture content of the formulated samples. This implies that product could be kept for a very long time. There was no significant $(p>0.05)$ difference between the ready-to-eat breakfast cereals from acha, mung bean and orange fleshed sweet potato flours as

Table 4. Total viable count and mould count of the formulated breakfast cereal.

\begin{tabular}{|l|l|l|}
\hline Sample & IVC $\mathbf{( c f u / g )}$ & Mould $(\mathbf{c f u} / \mathbf{g})$ \\
\hline UAC & $3.1 \times 103$ & ND \\
\hline UMB & $5.5 \times 103$ & ND \\
\hline ACMB1+OP1 & $4.7 \times 103$ & ND \\
\hline ACMB2+OP2 & $6.1 \times 103$ & ND \\
\hline ACMB3+OP3 & $8.3 \times 103$ & ND \\
\hline ACMB4+OP4 & $5.1 \times 103$ & ND \\
\hline ACMB5+OP5 & $3.6 \times 103$ & ND \\
\hline
\end{tabular}

Values are means of duplicate determinations. Key: AC: Acha flour; MB: Mung bean flour; OP: Orange fleshed sweet potato flour ;ND: Not detected; TVC: Total viable count; UAC: $100 \%$ Acha flour; UMB: $100 \%$ Mung bean flour; $\mathrm{ACMB}_{1}+\mathrm{OP}_{1}$ : $90 \%$ of best blend $+10 \%$ orange fleshed sweet potato; $\mathrm{ACMB}_{2}+\mathrm{OP}_{2}: 80 \%$ best blend $+20 \%$ orange fleshed sweet potato; $\mathrm{ACMB}_{3}+\mathrm{OP}_{3}=70 \%$ best blend $+30 \%$ orange fleshed sweet potato; $\mathrm{ACMB}_{4}+\mathrm{OP}_{4}=60 \%$ best blend $+40 \%$ orange fleshed sweet potato; $\mathrm{ACMB}_{5}+\mathrm{OP}_{5}=50 \%$ best blend $+50 \%$ orange fleshed sweet potato. well the control. These products were highly rated and acceptable to the panelists in terms of colour, taste, aftertaste, texture, appearance and overall acceptability.

\section{CONCLUSION}

The study showed that ready-to-eat breakfast cereals could be formulated from acha, mung bean and orange fleshed sweet potato which are presently underutilized. From the study, it was observed that among the breakfast cereals formulated from acha and mung bean flour, the judges preferred sample $A C+M B_{1}$ which was selected as the best blend. The breakfast cereals formulated from acha, mung bean and orange fleshed sweet potato flour were highly rated and acceptable to the panelists in all the attributes assessed. Thus, blending of acha, mung bean and orange fleshed sweet potato flour improved the acceptability and nutritional value of the resultant breakfast cereal.

It was also observed that decrease in the protein content of the breakfast cereal was improved by the addition of mung bean to the blend up to $12 \%$. The product resulting from the study also contain appreciable amount of carbohydrate which provides energy to the body when consumed. The inclusion of orange fleshed sweet potato to the blend improved the ash, fibre and $\beta$-carotene content of the breakfast cereal. The formulated breakfast cereals had very low microbial load while no mould was detected. The production of breakfast cereal from the raw materials used in this study would contribute to the nutritional needs of individuals who are protein and vitamin A deficient.

\section{REFERENCES}

AOAC (2010). Official Methods of Analysis.In: William Horwitz, and Dr. George Latimer (18 ${ }^{\text {th }}$ eds) Association of Official Analytical Chemists, Washington DC, USA.

Agu HO, Eze GC, Jideani AIO (2008). Quality assessment of acha-based biscuit improved with bambara nut and unripe plantain. Afr. J. Food. Sci. 8(5): 278-285.

Anwar F, Latif S, Przybylski R, Sultana B, Ashraf M (2007). Chemical composition and antioxidant activity of seeds of different cultivars of mungbean. J. Food. Sci. 72: $503-510$.

Ashraf A (2006). Nutritional improvement of an Egyptian breed of mungbean by probiotic lactobacilli. Afri. J. Biotechnol. 5(2): 206-212.

Bartova V, Barta J (2009). Chemical composition and nutritional value of protein concentrates isolated from potato (Solanum tuberosum L.) fruit juice by precipitation with ethanol or ferric chloride. J. Agric. Food. Chem. 57(19): 9028-9034.

Baskaran L, Sundaramoorthy P, Chidambaram A, Ganesh KS (2009). Growth and physiological activity 
of greengram (Vigna radiata L.) under effluent stress. Intern. J. Bot. 2(2): 107-114.

Belton PS, Nuttal JR (2002). Pseudocereals and less common cereals: Grains properties and utilization potential.In: Belton, Peter S., Taylor, John R.N (2 $2^{\text {nd }}$ eds) Springer, Berlin Heiderlberg.

Bovell-Benjamin AC (2007). Sweet Potato: A review of its past, present, and future role in human nutrition. Adv. Food. Nutr. Res. 52(1): 1 - 59.

Caulfield LE, Richard SA, Rivera JA, Musgrove P, Black RE (2006). Stunting, wasting, and micronutrient deficiency disorders. In: Disease Control Priorities in Developing Countries,In: Jamison DT, Breman JG, Measham AR, Alleyne G, Claeson M, Evans DB, Jha P, Mills $\mathrm{A}$ and Musgrove $\mathrm{P},\left(2^{\text {nd }}\right.$ eds). Oxford University Press and World Bank, Washington DC. 1-10.

Chukwu O, Abdul-kadir JA (2008). Proximate composition of acha (Digitaria exilis and Digitaria iburua) grains. J. Food. Technol. 6: 214-216.

Dewey K (2001). Breastfeeding: The evidence for breastfeeding. Paediatric. Clinics. of North. America, 48: 87-104.

Enwere NJ, Ntuen IG (2005). Effect of ripe fruit pulp on the sensory and nutritive quality of ready-to-eat breakfast cereal produced from maize and soybean flours and cassava starch. Intern. J. Food. Sci. Nutr. 56(1): 35-44.

Harrigan WF, McCance ME (1976). Laboratory Methods in Food and Diary Microbiology. Academic Press, London, UK. 25-29.

Hunty A, Ashwell M (2006). Are people who eat breakfast cereals regularly slimmer than those who don't? Nutri. Bull. 32(2): 1 - 10.

Igbabul B, Num G, Amove J (2014). Quality evaluation of composite bread produced from wheat, maize and orange fleshed sweet potato flours. Amer. J. Food. Sci. Technol. 2(4): 109-115.

Ihekoronye AI, Ngoddy PO (1985). Integrated Food Science and Technology for the Tropics, Macmillian Publishers Limited, London,UK: 236-253.

Jones JM (2003). Breakfast cereals and how they are made. The American Association of Cereal Chemists.

Kidane G, Abegaz K, Mulugeta A, Singh P (2013). Nutritional analysis of vitamin A enriched bread from orange flesh sweet potato and locally available wheat flours at Samre Woreda, Northern Ethiopia. J. Current. Nutr. Food. Sci. 1(1): 49-57.

Kirk RS, Sawyer R (1998). Pearson's Composition and Analysis of Foods. In: Addison-Wesley Longman Ltd ( $9^{\text {th }}$ eds) Churchill Livingstone, Edinburgh. 17-20.
Laryea D (2016). Formulation and characterization of sweetpotato-based complimentary food. Ph.D thesis. Department of Food Science and Technology, Kwame Nkrumah University of Science and Technology, Ghana.

Mbaeyi IE (2005). Production and evaluation of breakfast cereal using pigeon-pea (Cajanus cajan) and sorghum (Sorghum bicolor ), An M.Sc. dissertation of Department of Food Science and Technology, University of Nigeria, Nsukka.

Mbaeyi-Nwaoha IE, Uchendu NO (2016). Production and Evaluation of Breakfast Cereals from Blends of acha and Fermented Soybean Paste (Okara). J. Food. Sci. Technol. 53(1): 50-70.

Ofuya ZM, Akhidue V (2005). The role of pulses in human nutrition: A Review. J. Appl. Sci. Environ. Manag. 9(3): 99-104.

Okaka JC (2005). Handling, Storage and Processing of Plant Foods. Ocjanco Academic Publishers, Enugu,Nigeria. 30-60.

Olapade AA, Aworh OC (2012). Evaluation of extruded snacks from blends of acha (Digitaria exilis) and cowpea (Vigna unguiculata) flours. Agric. Eng. Intern. 14(3): 210 -217.

Omeire GC (2013). Physico-chemical properties of composite flours from blends of acha (Digiteria exilis), soyabean (Glycine max) and coconut (Cocos nucifera) and their use as breakfast meal. Intern. J. Basic. Appl. Sci. 2 (3): 112-117.

Onwuka GI (2005). Food Analysis and Instrumentation - Theory and practice, Naphtali prints, Lagos, Nigeria. pp 129-135.

Onwurafor EU, Onweluzo JC, Ezeoke AM (2014). Effect of fermentation methods on chemical and microbial properties of mung bean (Vigna radiata) flour. Nig. Food. J. 32(1): 89-96.

Prescott LM, Harley JP, Klein OA (2005). Microbial nutrition, types of media. In: Microbiology ( $6^{\text {th }}$ eds), McGraw Hill Publishers, New York. pp. 95-105.

Rampersaud GC, Pereira MA, Girard BL, Adams J, Metzl JD (2005). Breakfast habits, nutritional status, body weight, and academic performance in children and adolescents. J. Am. Diet. Asso. 105: 743-760.

Sharma JL, Caralli S (2004). A Dictionary of Food and Nutrition. CBS Publishers. New Delhi. 1-12.

Steel RG, Torrie JA (1980). Principles and Procedures of Statistics. A Biometrical Approach. (2 ${ }^{\text {nd }}$ eds) McGrawHill International, Auckland. 5-102.

Temesgen L, Abebe H, Tigist F (2015). Production and quality evaluation of cookies enriched with $\beta$-carotene by blending orange-fleshed sweet potato and wheat flours 
for alleviation of nutritional insecurity. Intern. J. Food. Sci. Nutr. Eng. 5 (5): 209-217.

Usman GO (2009). Production and evaluation of breakfast cereal made from blends of sorghum, soybeans and defatted coconut. An M.Sc dissertation of the Department of Food Science and Technology, University of Nigeria, Nsukka.
Vodouhe SR, Achigan DE, Dansi A, Adoukonou SH (2012). Fonio: A treasure for West Africa briefing by the International Plant Genetic Resources Institute (west and central Africa sub-office) and Crop, Aromatic and Medicinal plant Biodiversity Research and Development Institute (IRDCAM). 